\title{
Foraminifera as Environmental Condition Indicators in Todos os Santos Bay (Bahia, Brazil)
}

\author{
Patrícia Pinheiro Beck Eichler ${ }^{1,2 *}$, André Rösch Rodrigues ${ }^{3}$, \\ Evelyn da Rocha Mendes Pereira ${ }^{4}$, Beatriz Beck Eichler, \\ Alicia Kahn ${ }^{3}$, Helenice Vital ${ }^{1}$ \\ ${ }^{1}$ Programa de Pós Graduação em Geofísica e Geodinâmica (PPGG), Laboratório de Geologia e Geofísica \\ Marinha e Monitoramento Ambiental, Centro de Ciências Exatas e da Terra da Universidade Federal do Rio \\ Grande do Norte (GGEMMA-CCET-UFRN) Campus Universitário, Natal, Brazil \\ ${ }^{2}$ Universidade do Sul de Santa Catarina, UNISUL, Palhoca, Brazil \\ ${ }^{3}$ Chevron Energy Technology Company, Houston, USA \\ ${ }^{4}$ Instituto Oceanográfico da Universidade de São Paulo, São Paulo, Brazil \\ Email: ${ }^{*}$ patriciaeichler@gmail.com
}

Received 15 April 2015; accepted 25 July 2015; published 28 July 2015

Copyright (C) 2015 by authors and Scientific Research Publishing Inc.

This work is licensed under the Creative Commons Attribution International License (CC BY).

http://creativecommons.org/licenses/by/4.0/

(c) (i) Open Access

\section{Abstract}

The environmental quality of the marine area close to the Landulpho Alves Oil Refinery situated in Todosos Santos Bay (Bahia, Brazil) was assessed by statistical methods on foraminiferal assemblages, with species tolerant to low continental influence such as Ammonia tepida, Elphidium excavatum, Pseudononion atlanticum and Quinqueloculina spp., and to high organic matter such as Buliminella elegantissima and Bulimina marginata. We have found that Bolivina pulchella, Pseudononion atlanticum, Fursenkoina pontoni, Buliminella elegantissima, Bolivina striatula, Bulimina marginata, Quinqueloculina spp., Ammonia tepida, and Elphidium excavatum are opportunistic and tolerant to high levels of accumulated organic matter, and are associated to stations $6,17,18,19,21,22,23,24$, and 25 , located mainly in the southern, outermost part of the Bay.

\section{Keywords}

Foraminifera, Marine Environmental Quality, Organic Matter, Eutrophication, Continental Runoff, Opportunistic

\footnotetext{
*Corresponding author.
}

How to cite this paper: Eichler, P.P.B., Rodrigues, A.R., Pereira, E.R.M., Eichler, B.B., Kahn, A. and Vital, H. (2015) Foraminifera as Environmental Condition Indicators in Todos os Santos Bay (Bahia, Brazil). Open Journal of Ecology, 5, 326-342. http://dx.doi.org/10.4236/oje.2015.57027 


\section{Introduction}

The problems resulting from the pollution of coastal areas near urban and industrial centers in Brazil, as well as in several coastal countries, have been worsening rapidly. This has led to an ever-increasing number of environment protection entities, public health organizations and universities becoming involved in plans to assess and monitor pollutants in these areas. This is a subject to be tackled in a multidisciplinary way, taking into consideration the close interrelations linking the geological, physical, chemical and biological aspects inherent to the marine environment.

It is therefore worthwhile to consider the use of a proxy indicator that is simple to handle, inexpensive and reflects the environment's general features variations. Such a proxy must be sensitive enough to react rapidly to environmental variation and to pollution effects. In this sense, foraminiferal patterns of dominance and diversity are widely used since they respond to environmental stress and are commonly used in areas of oceanography and environmental monitoring [1], as well as in the assessment of organic and inorganic pollution [2] [3].

Several studies using foraminifera from confined coastal waters (lagoons, estuaries and mangroves) have been carried out in Brazil, however, most are limited to the species distribution. [4] performed qualitative studies on mangrove foraminifera in the Guaratiba region and in Sepetiba Bay (Rio de Janeiro State, Brazil). Mention should also be made of works by [5]-[10], who reaffirmed the importance of foraminifera in the ecological studies of coastal regions. There have been works correlating the distribution of foraminifera and water masses in São Paulo: Cananéia-Iguape estuarine system [11], São Sebastião Channel [12] and Juréia-Itatins ecological station [13], and evaluating foraminiferal responses to variations in salinity, dissolved oxygen and organic carbon in Guanabara Bay, Rio de Janeiro [14].

In relation to pollution, the use of benthic foraminifera as indicators was initiated by [15] and [16] in southern California. Since then, several works have focused on the effects of various types and sources of pollution in different marginal habitats [2] [17]-[19]. Before the last decade, most works have dealt with organic pollution, with only a minority dealing with pollution by oil or chemical products [3]. However, over the last decade, contributions on foraminiferal proxies for pollution monitoring have increased [20]-[22]. Concerning the evaluation of impacted areas in Brazil, [23] [24] have noted the importance of foraminiferal and thecamoebian assemblages in determining the ecological impact of Valo Grande (Iguape, São Paulo), and [14] [25]-[27] have described the foraminiferal assemblages characteristic of the polluted Guanabara Bay. More recently, in Laguna (Santa Catarina), [28] studying foraminifera as indicators of marine pollutant contamination on the inner continental shelf of southern Brazil inferred that the distribution of foraminiferal species is being distributed mostly by temperature, depth, salinity, and percentage of sand other than percentage of clay and total coliforms.

In this study, environmental quality of Todosos Santos Bay (TSB) was assessed quantitatively and qualitatively, through the distribution of foraminifera in the ecologically different environments of regions of Landulpho Alves Oil Refinery (RLAM) Sub-tidal area-stations 1 to 25 (Figure 1) and Caboto and Camamu controls (Cab 1, Cab 2, Cab 3, Cab 4, Cam 1, Cam 2, Cam 3, Cam 4).Camamu sites are from other coastal environment but are similar in physico-chemical characteristics to TSB. Only Caboto stations are located In Figure 1. The camamu mangrove is not within the Bay area and so it was not noted on the map. The control sites were chosen due to the similar physico-chemical characteristics and the relative distance from the RLAM. We assess the composition of foraminiferal assemblages in winter and summer for two consecutive years, in July and December 2003, July 2004 and January 2005, and to relate them to existing environmental variables due to seasonality. We intend to assess the occurrence of the different foraminifers' biofacies and to establish pollution and contamination bio indicators using data on organic carbon, unresolved complex mixture (UCM), polycyclic aromatic hydrocarbons (PAH), aliphatic levels and grain size from [29] and [30].

\section{Background}

The study area is located between $12^{\circ} 42^{\prime} \mathrm{S}-12^{\circ} 45^{\prime} \mathrm{S}$ and $38^{\circ} 32^{\prime} \mathrm{W}-38^{\circ} 36^{\prime} \mathrm{W}$ in the northeast portion of TSB (Figure 1). With an area of approximately $927 \mathrm{~km}^{2}$ it is the largest on the Brazilian coast. Water circulation within TSB is mainly controlled by tides, which are semidiurnal, being that high tidal currents flow towards north-northeast (NNE) and low tidal currents flow towards south-southwest (SSW) [31].

Studies have found temperature and salinity values indicated the presence of Coastal Water (CW) in TSB by [32], which is characterized by a temperature higher than $20^{\circ} \mathrm{C}$ and a salinity that varies approximately between 32.2 and 35.4 [33]. It is a shallow area with depths varying from 0.6 to $10 \mathrm{~m}$. An oil refinery of the PETRO- 


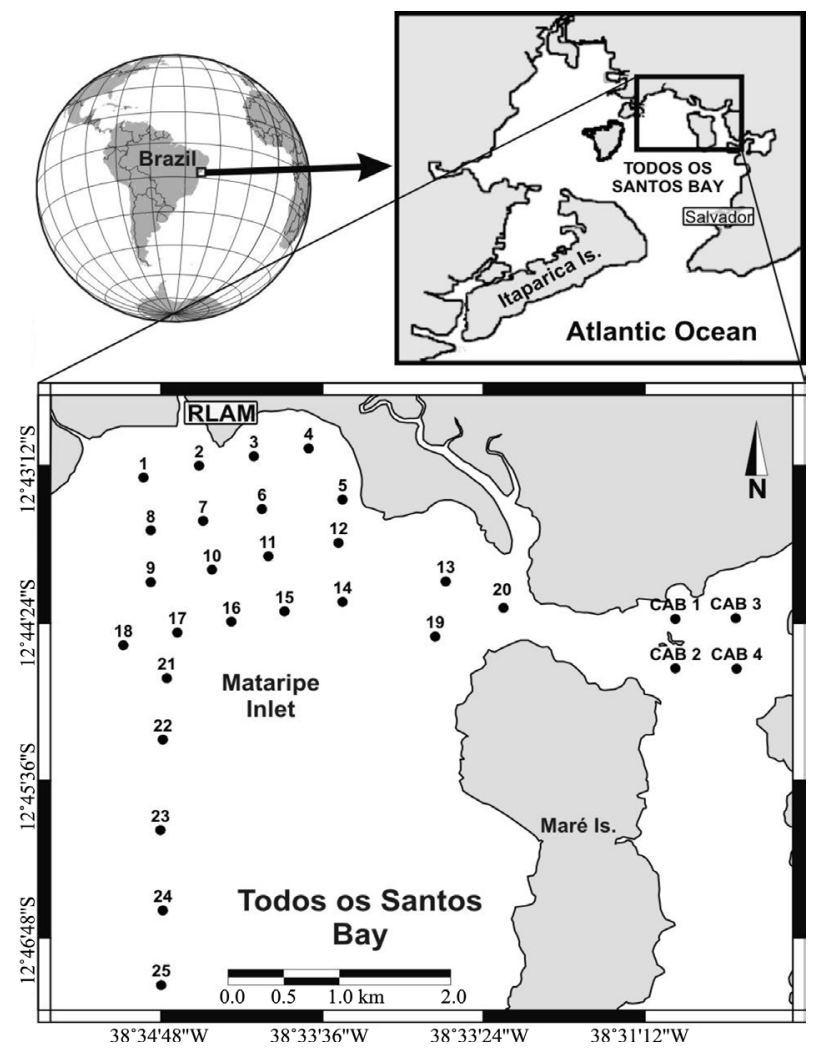

Figure 1. Study area, and the map of the RLAM subtidal stations where sediment samples for study of foraminifera were collected. Winter and summer 2003 sampling (stations 1 to 20) and winter 2004 and summer 2005 sampling (stations 1 to 25). Caboto sampling stations are also on the map (Cab 1 - Cab4).

BRAS Brazilian company "Refinaria Landulpho Alves-Mataripe" (RLAM) is situated adjacent to the study area and resultant effluents are discharged into it. Three rivers flow into the northeast portion of Todosos Santos Bay, the Caípe River, the Mataripe River and the São Paulo River. All of them flow through zones with mangrove vegetation and carry wastes from several industries and urban centers [31].

Silty sediments dominated in deep stations located in the center and in the east region of the TSB, whereas in shallow stations situated near the mouth of the three rivers, directly influenced by their inflow, sandy sediments were dominant. Highest content of total organic carbon, nitrogen and sulfur followed the distribution of silt and clay fractions [32]. These authors also suggested that total PAH concentrations in surface sediments of TSB were similar to those recorded in other coastal regions that receive large anthropogenic inputs derived from urban and industrial activities [34] [35].

Occurrence of petrogenic contamination with some pyrolytic input and the presence of degraded or weathered petroleum in sediments of TSB were presented by [32]. Near the oil refinery and in the central and in the east region of the TSB it was found evidence of relatively high PAH contamination, with some compounds at concentrations likely to cause adverse effects on benthic organisms. Since 1950, the area around TSB has been suffering increasing industrialization and exploitation of its natural resources [36]. Nowadays, effluents from 29 industries drain into the bay are responsible, together with urban and port activities, for considerable pollution problems.

\section{Materials and Methods}

\subsection{Sampling}

During the program's first year, two samplings (winter and summer of 2003) were carried out, and 20 stations sampled $(1$ - 20) in the subtidal zone of the Landulpho Alves Oil Refinery (RLAM) area. No sampling was per- 
formed at the control stations located in the Caboto and Camamu mangrove. In the second year of sampling (winter and summer, 2005), five stations were added to the sampling network (21-25) of the RLAM subtidal area, and sediments were also collected at four stations situated in each one of the control regions (Camamu and Caboto) (Figure 1). Sediment sampling was carried out at water depth of 2 and $10 \mathrm{~m}$. Samples collected with van veen grabs were sub-sampled with spatulas, and about $10 \mathrm{~cm}^{3}$ of sediment removed, preferentially from the top layer $(2 \mathrm{~cm})$. The material collected was stained with Rose bengal diluted in alcohol, so as to stain the cytoplasm of the specimens alive at the time of sampling.

\subsection{Laboratory}

This material was washed in 0.500 - and $0.062-\mathrm{mm}$ sieves to remove silt and clay, and oven dried at $60^{\circ} \mathrm{C}$. Fractions were floated in trichloroethylene $\left(\mathrm{C}_{2} \mathrm{HCL}_{3}\right)$, so as to facilitate the separation of foraminiferal tests from terrigenous grains [37]. After separation, the biological material was sorted, and only the live foraminifera specimens were transferred, with the aid of a brush, to slides with a black background for later identification. Foraminifera tests were considerated live specimens when its test was all stained. Determination of the species was performed using a Zeiss Stemi SV11stereo microscope.

\subsection{Analysis of the Results}

\subsubsection{Descriptive Statistics}

Living foraminiferal species were counted per sampled station, then the species' relative abundance was calculated.

Maps of foraminiferal spatial distribution were drawn up using a geographic information system (SURFER 8.0), which relates each datum to its geographic coordinates.

\subsubsection{Analytical Statistics}

Diversity, dominance and evenness indices: Univariate techniques that encompass diversity, dominance and evenness indices are effective when used together to assess changes in community structure. The indices calculated in the present study were Shannon-Wiener diversity to the base $e$ [38], Simpson's dominance index and Pielou evenness index [39]. Calculations were done with the University of Plymouth Primer program, as described in [40].

Multivariate analysis: To corroborate the descriptive statistics, Non-metric multi-dimensional scaling analysis (MDS) was applied using PRIMER program. In these analyses Bray-Curtis biological similarity matrices were used, with $\log (x+1)$ transformed absolute data. Groups in non-metric multidimensional scaling (MDS), are formed based on foraminiferal data producing a "map" of samples in which the placement of samples reflects the similarity of their biological communities and environmental patterns, rather than their geographical location.

To assess the degree of environmental pollution the hypoxia index (A-E index) described by [41] was used. This index is currently used to determine the degree of sediment hypoxia according to the absolute abundance of two common species in coastal environments (Elphidium excavatum and Ammonia tepida). Species of these genera are tolerant to hypoxia, although species of Elphidium are less resistant than those of Ammonia.

The $A-E$ index is calculated by the formula:

$$
\frac{\text { A.B.Ammonia }}{\text { A.B.Ammonia }+ \text { A.B.Elphidium }} \times 100
$$

where: $A . B .=$ absolute abundance (number of individuals $/ 50 \mathrm{~cm}^{3}$ )

Values of the A-E index and the distribution of Ammonia tepida were plotted in Scatter plots correlating the percentage of organic carbon to the concentration of PAH to assess the patterns present in the samples. Analysis of tests fragmentation: Tests were observed in relation to the state of test preservation, due to acidity and transportation. These analyses were qualitatively estimated.

\section{Results}

\subsection{General Species Distribution}

It can be visualized that Ammonia tepida presented highly expressive abundance (more than 30\%) with a notable 
decrease at station 06 (Figure 2).

Elphidium excavatum, on the other hand, presented abundance increase at station 14, particularly in July 2004. This pattern was still more marked in the two summer samplings (Figure 3).

Buliminella elegantissima presented a similar pattern in July 2003, December 2003 and January 2005, with a peak of occurrence especially at station 15 (Figure 4).

In July 2003, Pseudononion atlanticum occurred at stations 13, 14, 17, 18, and in January 2005 the occurrence of this species at stations 2, 3, 4, 6, 14, 16, and 20 is very low (Figure 5).

Quinqueloculina spp. were dominante especially at stations 4 and 6, and had lower relative abundances at stations 16, 17, 18, 21 and 22. The patterns observed in the winter were quite similar to those found in the summer, and the pattern repeated itself from one year to the next with few variations (Figure 6).

In all samplings, Ammonia tepida predominated in the region, followed by species characteristic of marine environments under little influence from continental runoff such as Elphidium excavatum, Pseudononionatlanti-

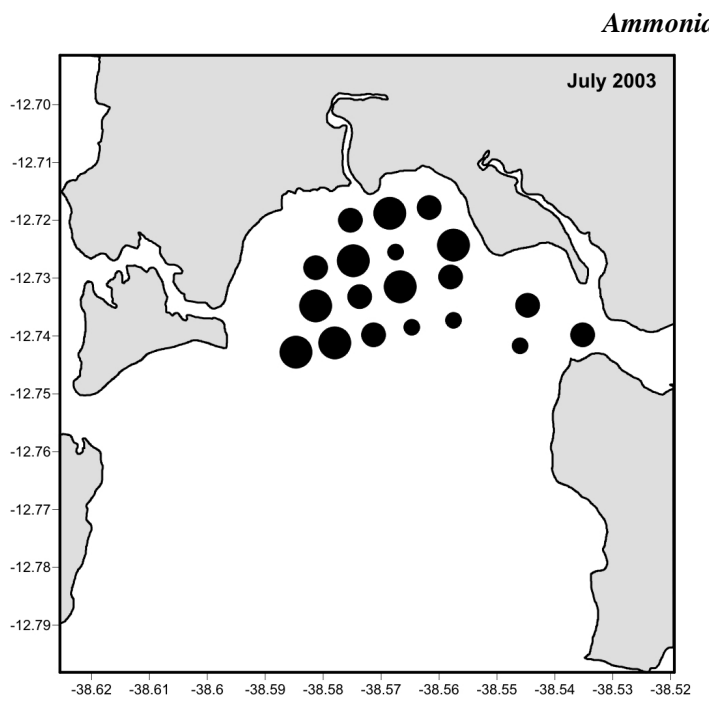

(a)

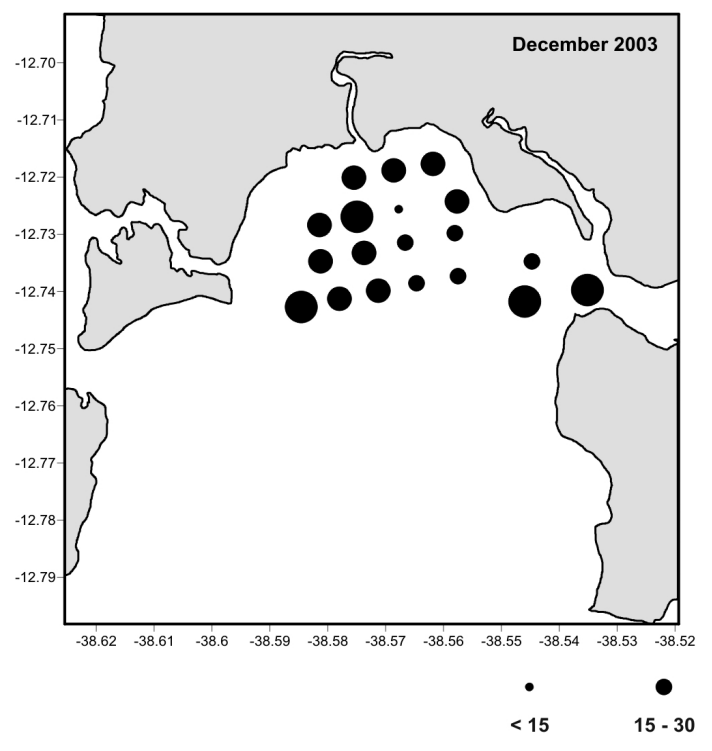

(c)

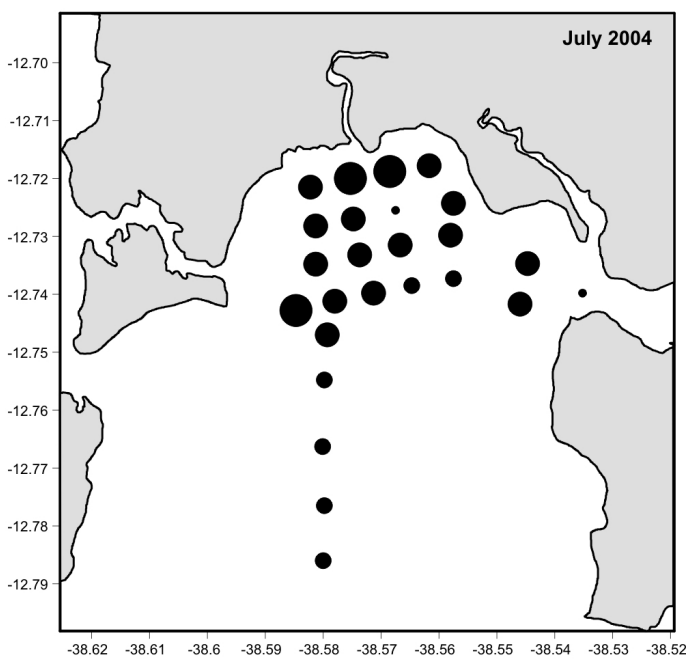

(b)

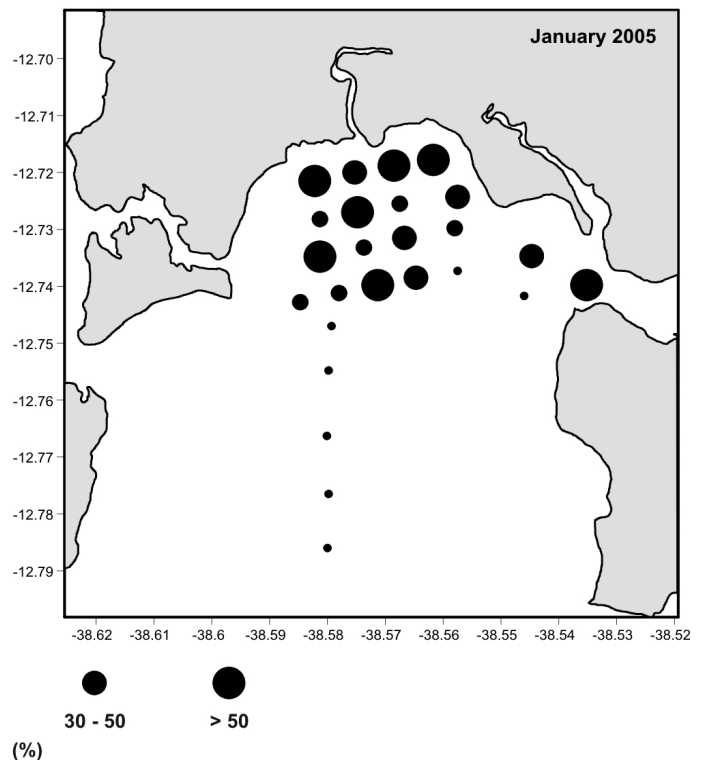

(d)

Figure 2. Relative abundance of Ammonia tepida in the sediment collected in the RLAM subtidal area in the winter (July 2003 and July 2004) and in the summer sampling (December 2003 and January 2005). 


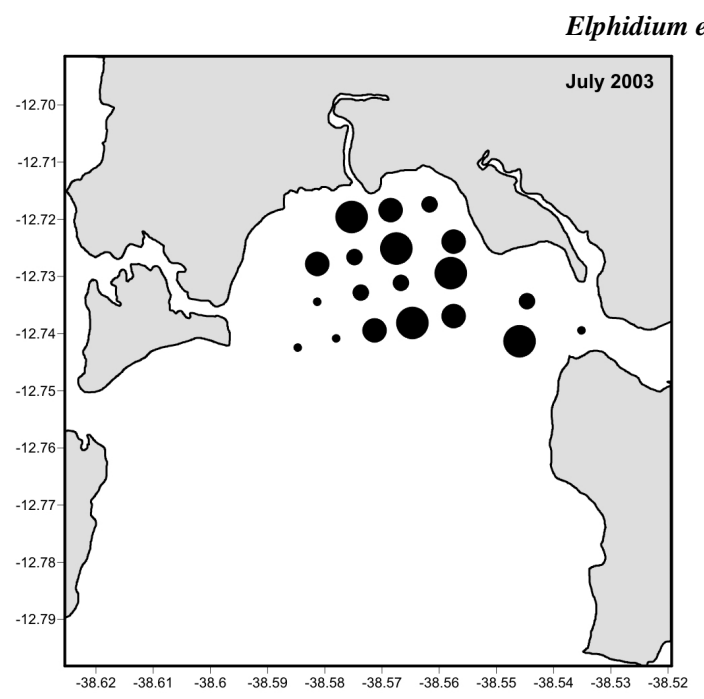

(a)

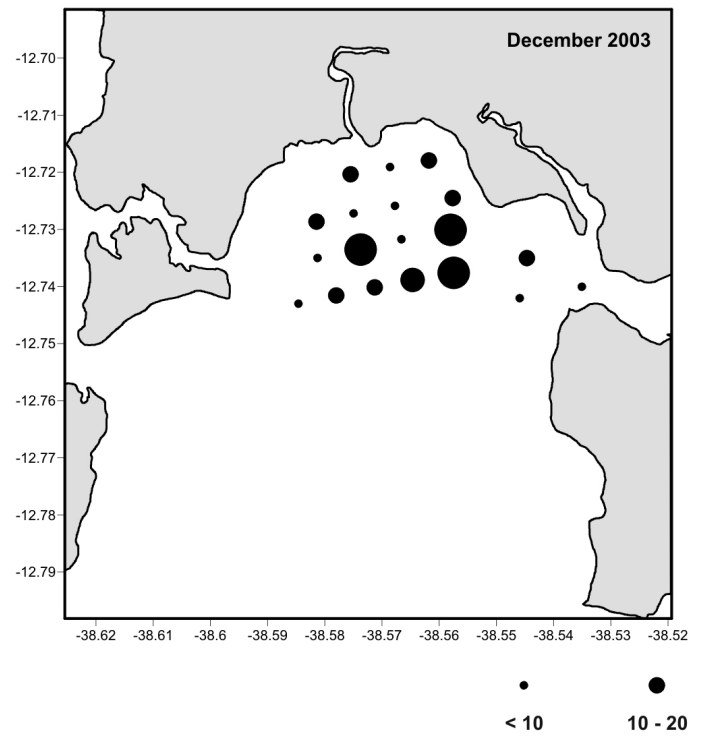

(c)

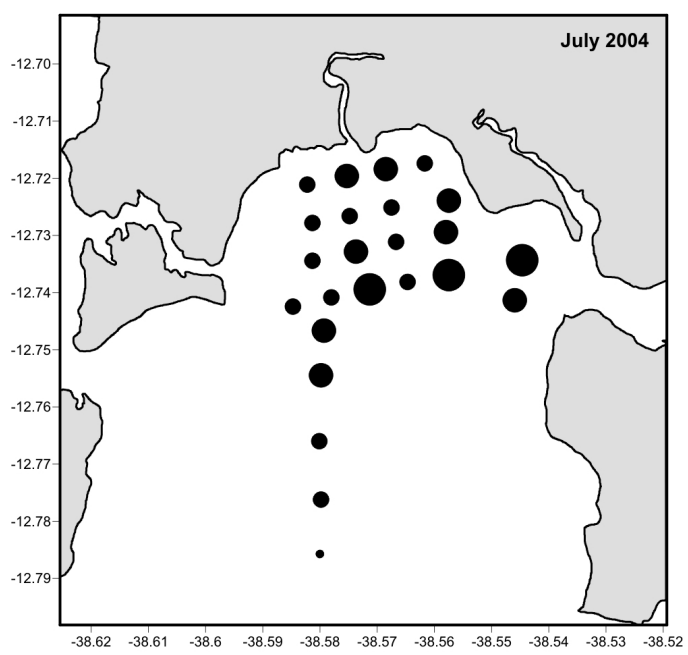

(b)

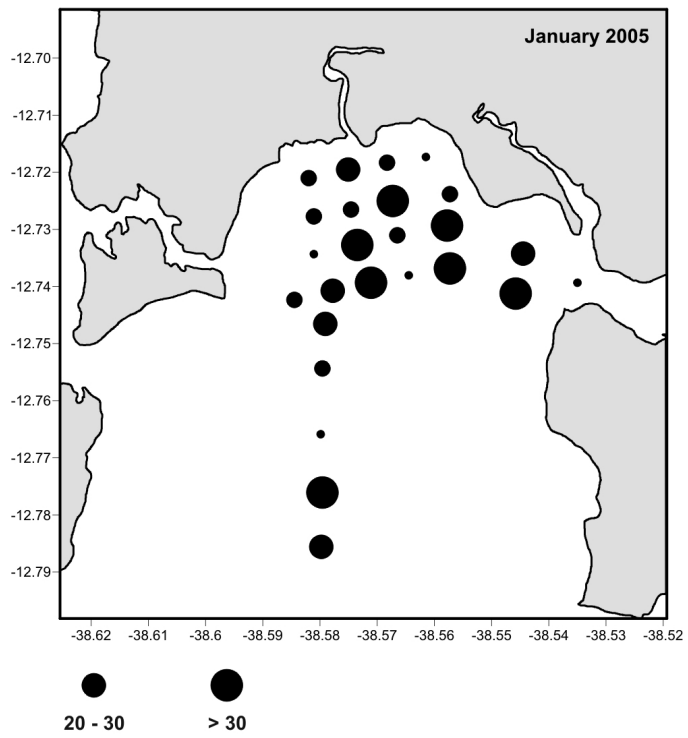

(d)

Figure 3. Relative abundance of Elphidium excavatum in the sediment collected in the RLAM subtidal area in the winter (July 2003 and July 2004) and in the summer sampling (December 2003 and January 2005).

cum, Quinqueloculina spp. The presence of agglutinated forms (Gaudryinaexilis, Ammotium spp., Haplophragmoideswilberti, Arenoparrellamexicana, Trochammina sp.) was also found, indicating high influence from continental runoff in some stations. No anomalies in foraminiferal tests were detected.

Foraminiferal relative abundances from winter and summer samplings are given in supplementary data. Fragmented tests of Ammonia tepida, Elphidium excavatum, Quinqueloculina spp. occurred more in the winter than in the summer. In the winter, the highest number of species with fragmented tests occurred at station 17, while in the highest number of fragmented tests was at station 25. These data can also be found in the supplementary data.

\subsection{Diversity, Dominance and Evenness}

Diversity, dominance and evenness data are presented in Table 1 (winter sampling July 2003 and July 2004) and 
Buliminella elegantissima

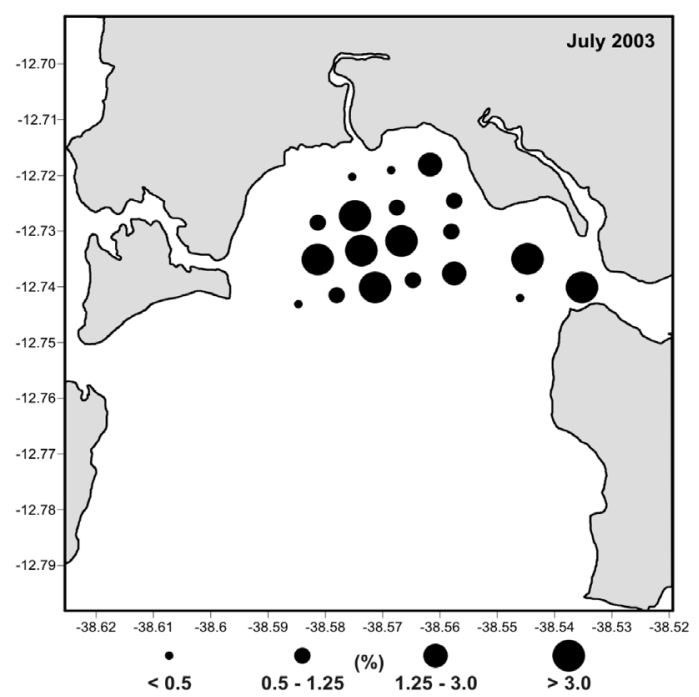

(a)

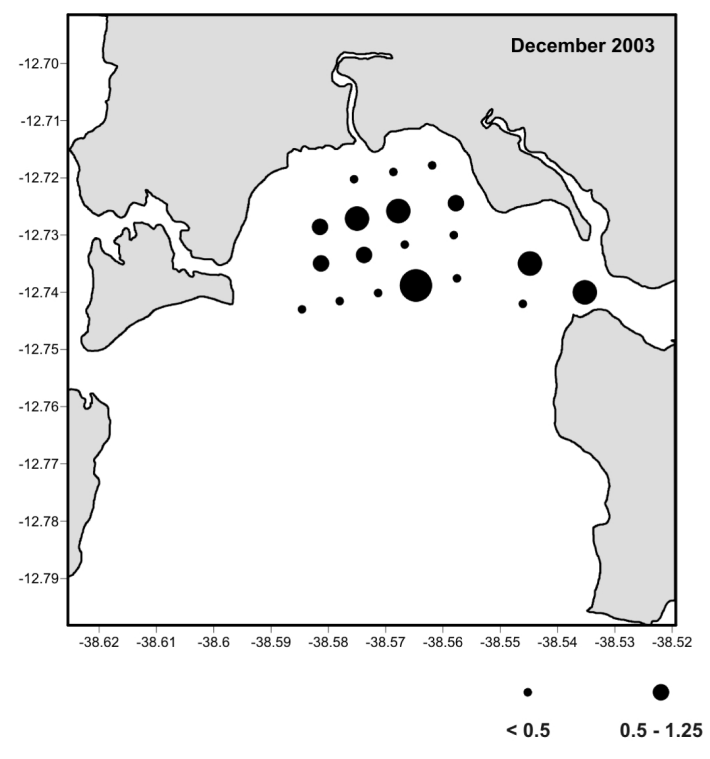

(c)

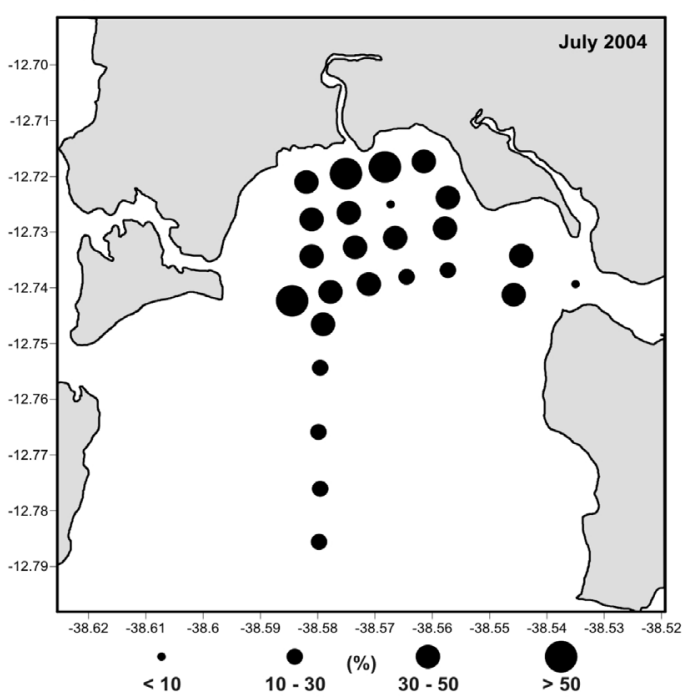

(b)

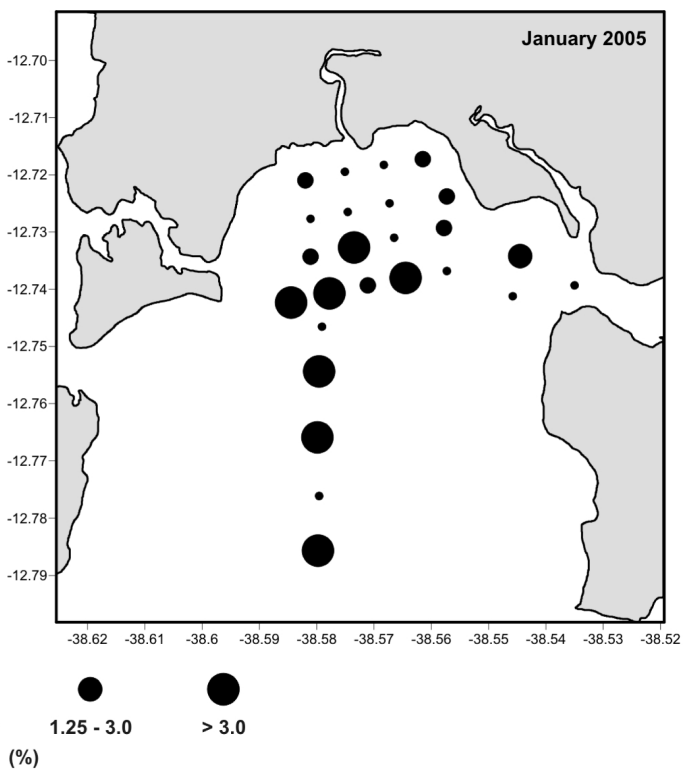

(d)

Figure 4. Relative abundance of Buliminella elegantissima in the sediment collected in the RLAM subtidal area in the winter (July 2003 and July 2004) and in the summer sampling (December 2003 and January 2005).

in Table 2 (summer sampling December 2004 and January 2005). It was noted that both in the winter of 2004 and in the summer of 2005 the Caboto and Camamu stations presented less diversity as compared to the RLAM subtidal area.

In all samplings it was observed decrease in diversity and increase in Ammonia tepidadominance in stations 1 to 4 of the RLAM subtidal area. An increase in diversitywas found at stations 21 to 25. Among the mangrove samples, stations Cab 2, Cab 3, Cam 1 and Cam 2 presented higher diversity and lower dominance and evenness.

\subsection{MDS}

In the MDS analysis using all the stations sampled in the winter of 2004 (Figure 7(A1)), the similarity of the 
Table 1. Diversity, dominance and evenness data from winter sampling (July 2003 and July 2004).

\begin{tabular}{|c|c|c|c|c|c|c|c|}
\hline Jul-04 & Evenness & Diversity & Dominance & Jul-03 & Evenness & Diversity & Dominance \\
\hline 1 & 0.66 & 1.44 & 0.29 & 2 & 0.63 & 1.32 & 0.31 \\
\hline 2 & 0.59 & 1.30 & 0.37 & 3 & 0.58 & 1.21 & 0.40 \\
\hline 3 & 0.52 & 1.21 & 0.43 & 4 & 0.61 & 1.19 & 0.37 \\
\hline 4 & 0.67 & 1.08 & 0.38 & 5 & 0.53 & 1.04 & 0.44 \\
\hline 5 & 0.62 & 1.43 & 0.33 & 6 & 0.77 & 1.92 & 0.18 \\
\hline 6 & 0.75 & 1.73 & 0.25 & 7 & 0.65 & 1.79 & 0.30 \\
\hline 7 & 0.79 & 1.74 & 0.22 & 8 & 0.67 & 1.76 & 0.28 \\
\hline 8 & 0.75 & 1.81 & 0.22 & 9 & 0.62 & 1.69 & 0.33 \\
\hline 9 & 0.74 & 2.05 & 0.20 & 10 & 0.68 & 1.74 & 0.28 \\
\hline 10 & 0.70 & 2.03 & 0.21 & 11 & 0.63 & 1.57 & 0.35 \\
\hline 11 & 0.73 & 1.87 & 0.26 & 12 & 0.67 & 1.72 & 0.24 \\
\hline 12 & 0.67 & 1.95 & 0.22 & 13 & 0.78 & 2.13 & 0.16 \\
\hline 13 & 0.68 & 1.56 & 0.29 & 14 & 0.81 & 1.86 & 0.18 \\
\hline 14 & 0.56 & 1.55 & 0.32 & 15 & 0.66 & 1.64 & 0.27 \\
\hline 15 & 0.91 & 2.26 & 0.12 & 16 & 0.69 & 1.53 & 0.31 \\
\hline 16 & 0.99 & 1.09 & 0.34 & 17 & 0.66 & 1.38 & 0.34 \\
\hline 17 & 0.80 & 1.98 & 0.18 & 18 & 0.73 & 1.31 & 0.36 \\
\hline 18 & 0.66 & 1.58 & 0.33 & 19 & 0.66 & 1.38 & 0.33 \\
\hline 19 & 0.63 & 1.52 & 0.32 & 20 & 0.74 & 1.55 & 0.30 \\
\hline 20 & 0.84 & 1.94 & 0.17 & & & & \\
\hline 21 & 0.67 & 1.66 & 0.27 & & & & \\
\hline 22 & 0.72 & 1.95 & 0.20 & & & & \\
\hline 23 & 0.96 & 2.11 & 0.13 & & & & \\
\hline 24 & 0.93 & 2.40 & 0.11 & & & & \\
\hline 25 & 0.94 & 2.73 & 0.08 & & & & \\
\hline Cab 01 & 0.48 & 0.86 & 0.59 & & & & \\
\hline Cab 02 & 0.76 & 1.48 & 0.28 & & & & \\
\hline Cab 03 & 0.78 & 0.85 & 0.50 & & & & \\
\hline Cab 04 & 0.54 & 0.75 & 0.61 & & & & \\
\hline Cam 01 & 0.91 & 1.63 & 0.22 & & & & \\
\hline Cam 02 & 0.66 & 1.69 & 0.27 & & & & \\
\hline Cam 03 & 0.63 & 1.56 & 0.30 & & & & \\
\hline Cam 04 & 0.81 & 1.12 & 0.37 & & & & \\
\hline
\end{tabular}


Table 2. Diversity, dominance and evenness data from summer sampling (December 2003 and January 2005).

\begin{tabular}{|c|c|c|c|c|c|c|c|}
\hline Dec-03 & Evenness & Diversity & Dominance & Jan-05 & Evenness & Diversity & Dominance \\
\hline 2 & 0.61 & 1.19 & 0.37 & 1 & 0.60 & 1.82 & 0.30 \\
\hline 3 & 0.53 & 1.17 & 0.37 & 2 & 0.69 & 1.43 & 0.32 \\
\hline 4 & 0.71 & 0.98 & 0.42 & 3 & 0.36 & 0.71 & 0.67 \\
\hline 5 & 0.69 & 1.23 & 0.35 & 4 & 0.56 & 1.09 & 0.47 \\
\hline 6 & 0.75 & 1.91 & 0.19 & 5 & 0.75 & 1.66 & 0.25 \\
\hline 7 & 0.59 & 1.36 & 0.38 & 6 & 0.65 & 1.72 & 0.24 \\
\hline 8 & 0.60 & 1.43 & 0.32 & 7 & 0.71 & 1.15 & 0.40 \\
\hline 9 & 0.68 & 1.64 & 0.28 & 8 & 0.72 & 1.67 & 0.26 \\
\hline 10 & 0.68 & 1.48 & 0.30 & 9 & 0.48 & 1.19 & 0.51 \\
\hline 11 & 0.77 & 1.84 & 0.20 & 10 & 0.71 & 2.34 & 0.18 \\
\hline 12 & 0.70 & 1.67 & 0.24 & 11 & 0.69 & 1.95 & 0.26 \\
\hline 13 & 0.82 & 1.96 & 0.18 & 12 & 0.65 & 2.04 & 0.21 \\
\hline 14 & 0.58 & 1.12 & 0.43 & 13 & 0.70 & 2.14 & 0.18 \\
\hline 15 & 0.94 & 1.83 & 0.18 & 14 & 0.56 & 1.16 & 0.46 \\
\hline 16 & 0.84 & 1.84 & 0.19 & 15 & 0.73 & 1.43 & 0.30 \\
\hline 17 & 0.76 & 1.59 & 0.27 & 16 & 0.58 & 0.93 & 0.47 \\
\hline 18 & 0.91 & 1.26 & 0.31 & 17 & 0.80 & 2.25 & 0.14 \\
\hline 19 & 0.95 & 1.32 & 0.28 & 18 & 0.83 & 2.54 & 0.10 \\
\hline \multirow[t]{15}{*}{20} & 0.45 & 0.94 & 0.56 & 19 & 0.77 & 2.04 & 0.16 \\
\hline & & & & 20 & 0.76 & 1.05 & 0.40 \\
\hline & & & & 21 & 0.79 & 2.07 & 0.16 \\
\hline & & & & 22 & 0.97 & 2.90 & 0.06 \\
\hline & & & & 23 & 0.93 & 2.83 & 0.07 \\
\hline & & & & 24 & 0.94 & 2.49 & 0.09 \\
\hline & & & & 25 & 0.93 & 2.78 & 0.07 \\
\hline & & & & Cab 01 & 0.81 & 0.89 & 0.47 \\
\hline & & & & Cab 02 & 0.98 & 1.59 & 0.21 \\
\hline & & & & Cab 03 & 0.88 & 1.23 & 0.33 \\
\hline & & & & Cab 04 & 0.63 & 0.70 & 0.62 \\
\hline & & & & Cam 01 & 0.64 & 1.54 & 0.30 \\
\hline & & & & Cam 02 & 0.65 & 2.05 & 0.21 \\
\hline & & & & Cam 03 & 0.59 & 1.42 & 0.37 \\
\hline & & & & Cam 04 & 0.75 & 0.83 & 0.52 \\
\hline
\end{tabular}



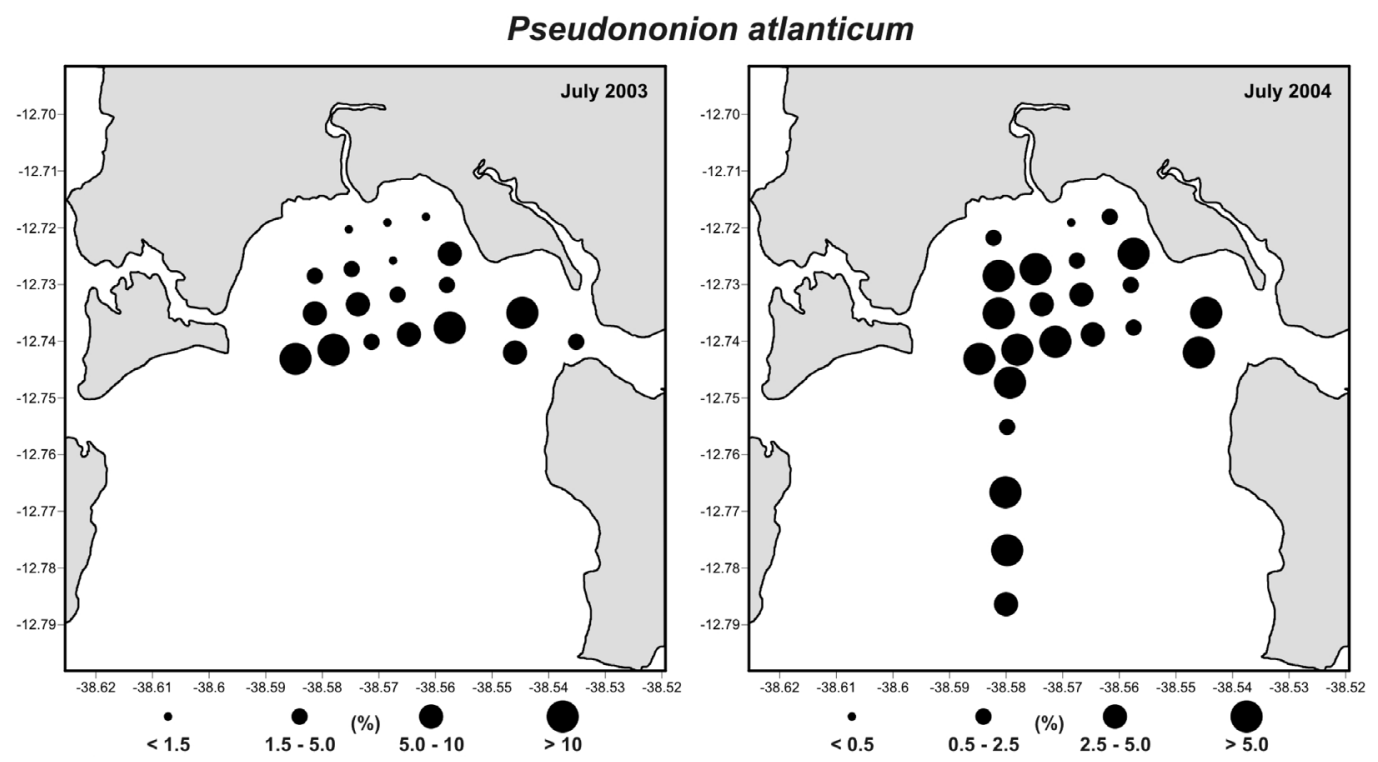

(a)
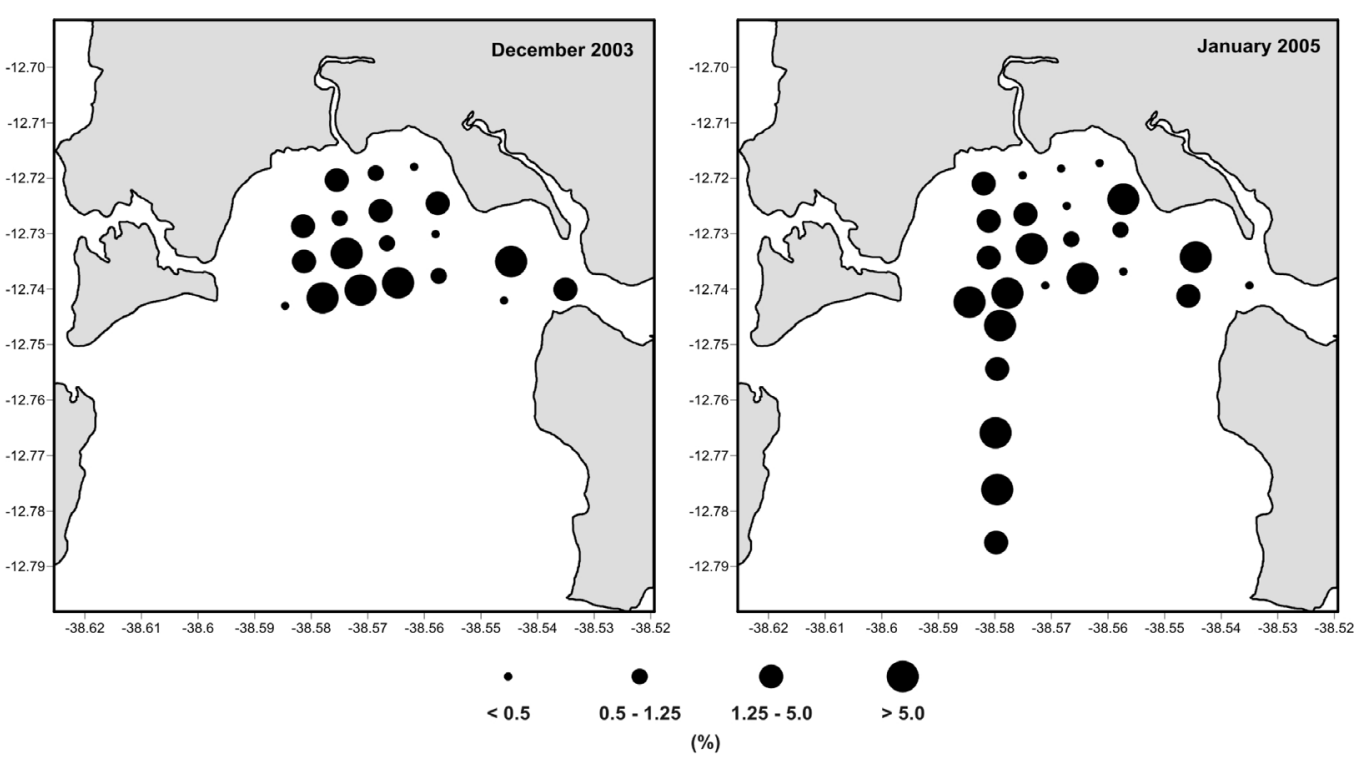

(c)

(d)

Figure 5. Relative abundance of Pseudononion atlanticum in the sediment collected in the RLAM subtidal area in the winter (July 2003 and July 2004) and in the summer sampling (December 2003 and January 2005).

stations in terms of foraminifera species found stood out, however, it can be visualized that stations 20, Cab 1 to Cab 4, Cam 1 and Cam 4 presented differentiated fauna. A new MDS analysis disregarding the control stations (Caboto and Camamu) and station 20, was thus performed (Figure 7(B1)).

These samples were removed because they presented few individuals, low species numbers and the smallest diversities, suggesting that the station 20 and control areas are not environments once thought very similar to those in the RLAM area and, therefore, are not wholly comparable. Also, the lack of continual data from the control areas hampers comparison between the two consecutive years. By removing these stations from the MDS analysis, it was possible to see that in July 2004 the rest of the samples formed three groups with more similarity between stations. One group comprised stations 22, 23, 24, and 25; another one stations 1, 2, 3, 4, 5 and 6 , and the last group, stations $9,10,11,12,14,18$, and 19. In December 2003, visualization of these groups was even clearer. In January 2005 (A2) it could be observed that the control stations were also less similar to those of 


\section{Quinqueloculina spp.}

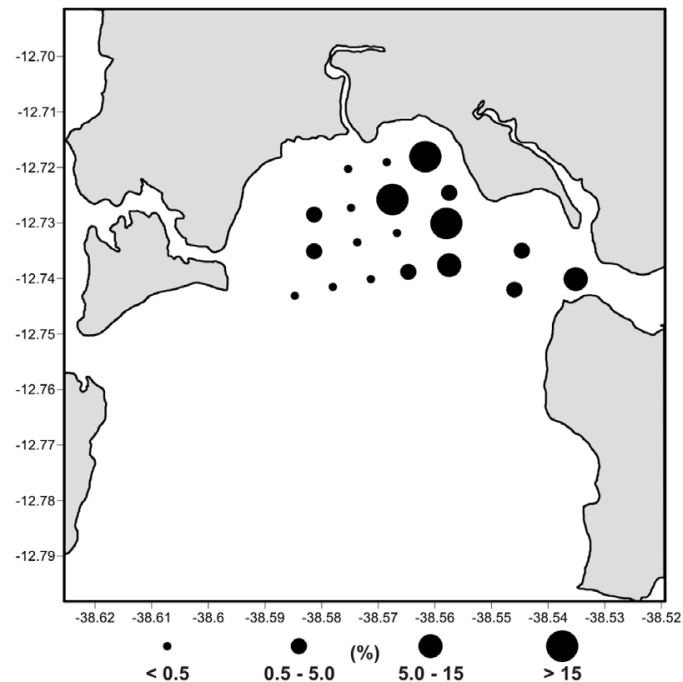

(a)

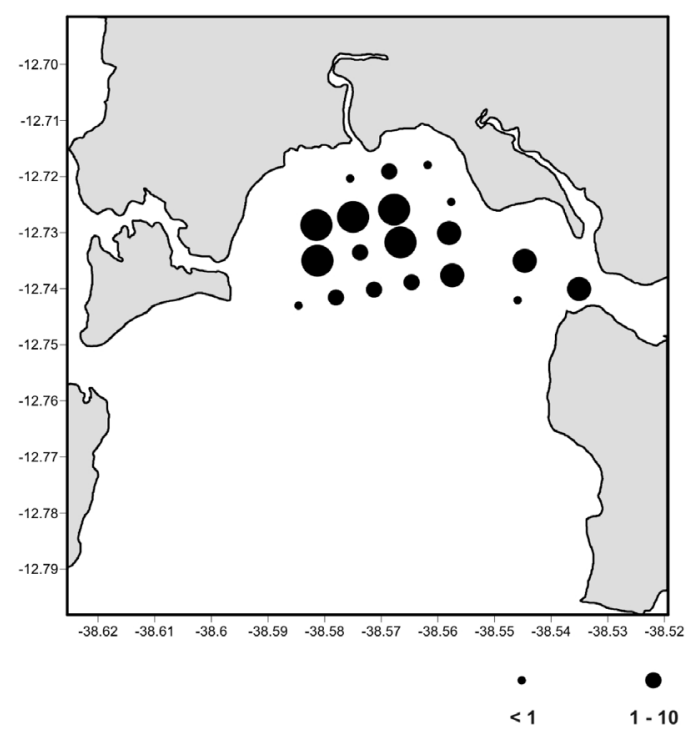

(c)

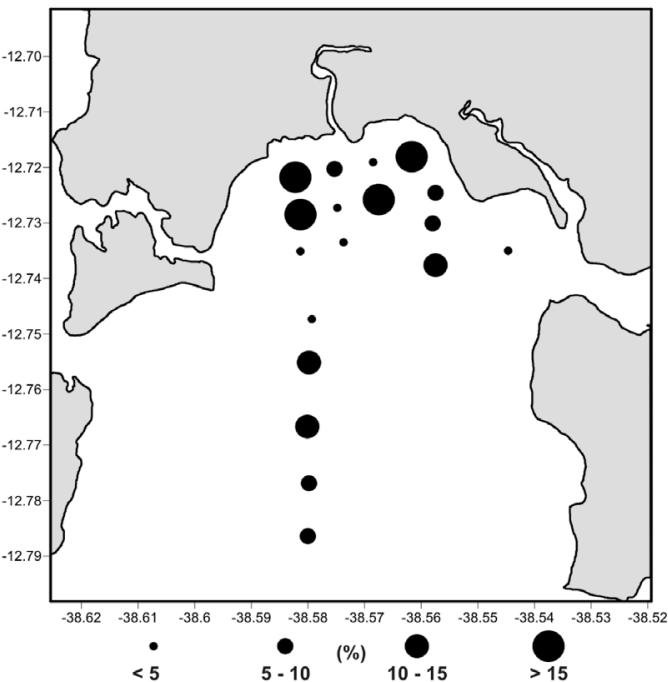

(b)

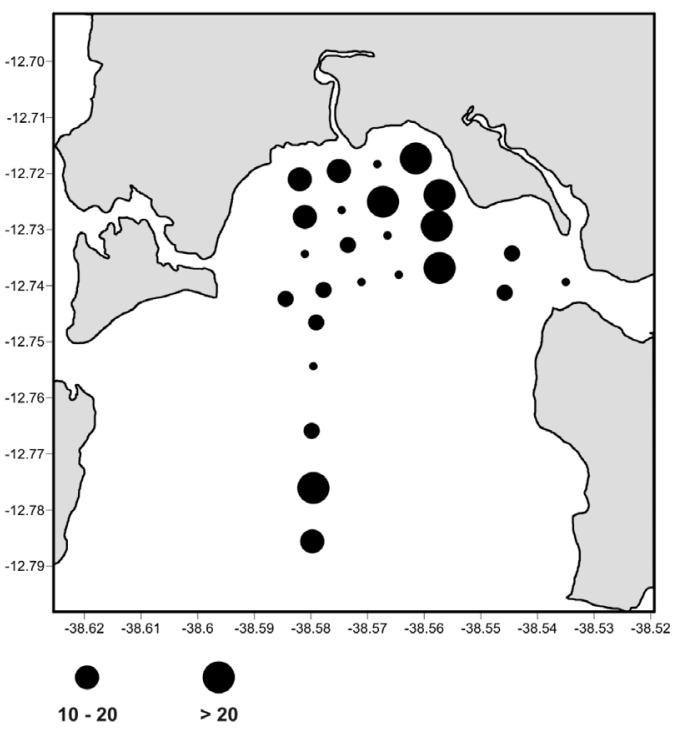

(d)

Figure 6. Relative abundance of Quinqueloculina spp. in the sediment collected in the RLAM subtidal area in the winter (July 2003 and July 2004) and in the summer sampling (December, 2003 and January, 2005).

the RLAM subtidal area and were also removed from the analysis. In B2 the formation of main groups could be observed, similar to those groups found in July 2004 and December 2003.

\subsection{Scatter Plots with Tendency Lines}

In January 2005, high positive correlation was found between organic carbon and PAH ( $\left.\mathrm{R}^{2}: 0.7603\right)$ and low positive correlation was found between the $A E$ index and organic carbon $\left(R^{2}: 0.2173\right)$ (Figure 8(a) and Figure 8(b)).

\section{Discussion}

The study of foraminifera in the RLAM subtidal area and in the control samples showed the occurrence of spe- 


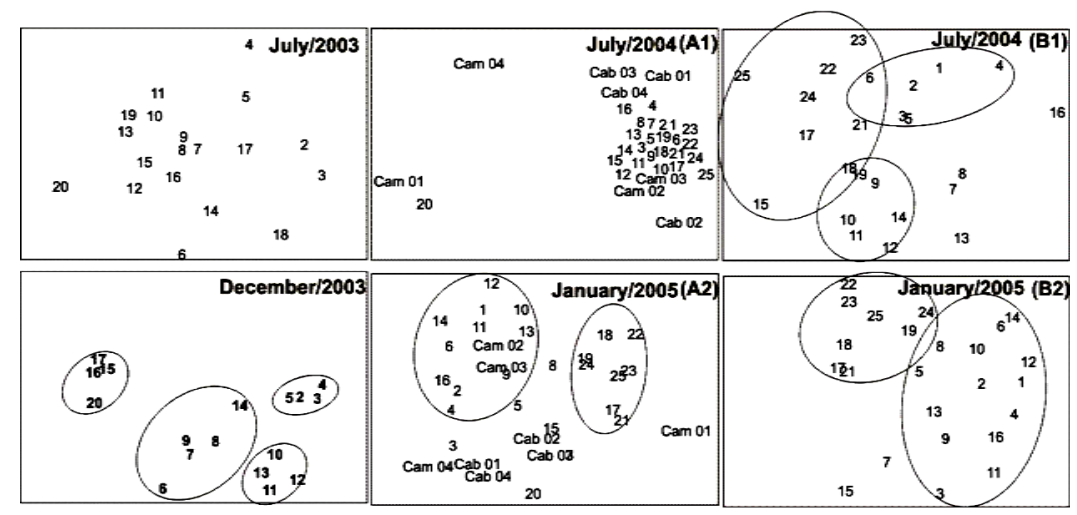

Figure 7. MDS analysis on the foraminiferal fauna. July 2003; July 2004, where (A1) represents the analysis performed on all stations and (B1) with stations 20, Caboto and Camamu removed; December 2003; and January 2005 where (A2) represents the analysis performed on all stations and (B2) with stations Caboto and Camamu removed.

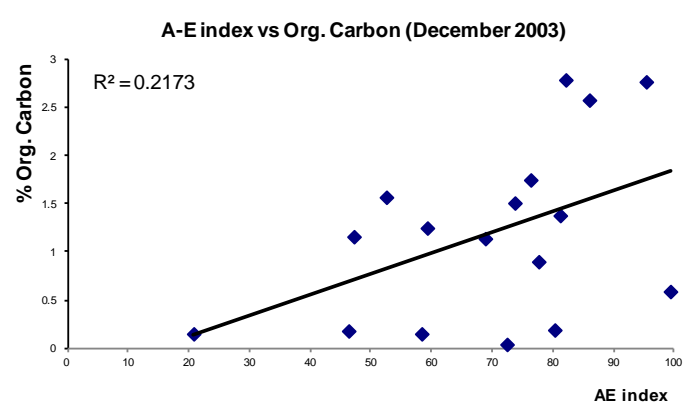

(a)

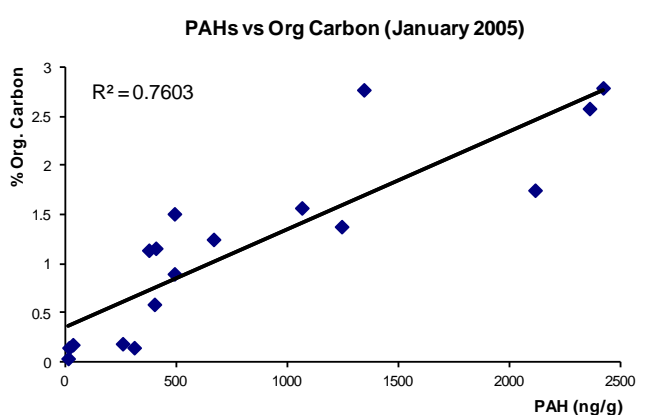

(b)

Figure 8. (a) Graph of PAH vs organic carbon in the summer (January 2005) sampling; (b) Graph of A-E index vs organic carbon in the summer sampling (December 2003).

cies from marine environments under low continental runoff influence such as Ammonia tepida, Elphidium excavatum, Pseudononion atlanticum, Buliminella elegantissima and Quinqueloculina spp., and the presence of agglutinated forms, indicating higher continental runoff influence in certain areas. The type of fauna found in TSB indicates that the environment is dominated by marine waters. In Rehoboth Bay (Delaware, USA), [43] verified that the abundance ratio between Ammonia tepida and Elphidiumpoeyanum reflects local variations in temperature and salinity. Ammonia tepida is the more abundant species in the warmer, less saline parts of the inner bay near freshwater sources, while $E$. poeyanum predominates in the colder, more saline outer bay in the vicinity of the marine inlet. Their results indicate that the foraminiferal assemblages correlate well $(r=0.881)$ with the spatial variations in environmental factors, notably temperature, salinity, and bottom-water dissolved oxygen, all of which have gradients with water depth. On the other hand, the low diversity and strong dominance of a few species in the TSBmay be characteristic of estuarine environments where fresh water limits organism distribution, or yet of ill-preserved environments like what was reported in Guanabara Bay (RJ) by [14].

The presence of morphological deformities in foraminifers as a response to heavy metal pollution is widely discussed in the literature ([3] [44], among others), but on the other hand, the absence of deformed species does not mean that the environment is free from contamination. Corroborating this statement, [45] detected the presence of deformities in the foraminiferal tests at Juréia-Itatins ecological station and these deformities were attributed to strong tidal currents acting in that preserved region. It must be noted that fragmented tests found in the abovementioned study are not related to morphological deformities, but rather to local hydrodynamic effects.

The opportunistic species Buliminella elegantissima, known for its high tolerance to high organic matter content [11] [18] [46]-[48] ), presented the highest abundance in winter (July 2003) closer to the river mouth with respect to summer samplings (December 2003 and January 2005). Occurrence peaks for this species were found 
especially at stations 13 and 15, where PAH levels were high, and UCM and aliphatic levels, low. The low presence of B. elegantissima and of $P$. atlanticum at stations 2, 3, 6, 7 and 8 suggests the influence of continental runoff in winter and summer. These are species that occur in estuarine environments more associated with strong marine influence (i.e., sea-level salinity). The dominance of Ammonia tepida, especially at stations 4, 7, 8, 9, 10, 11 and 15, where the highest PAH, found by [29] and [30], reaffirms its status as an opportunistic species. On the other hand, our study also showed Elphidium excavatum dominating at station 14, where there was a decrease in PAH.

Our study showed that there is a slight positive correlation of AE index and organic carbon of $22 \%$, in agreement with [49] where the increase of the AE index correlates well with the overall rise in the oxygen stress, in Louisiana continental shelf in water depths of 20 to $30 \mathrm{~m}$. It can therefore, be inferred that the increase in the organic carbon in the study area is possible linked to the increase in the hypoxia.

The number of species per sample increases when the environmental features are more typically marine [50]. It was thus to be expected that TSB presented higher diversity than more restricted estuarine environments. Although TSB is under the influence of continental runoff in the summer and winter, the foraminiferal assemblages indicate that this influence is quite small. Comparison of the present study with the data obtained by [23] [24] in the Cananéia-Iguape estuarine system (São Paulo State) and the data by [51] in Conceição Lagoon (Santa Catarina State) in two restricted environments shows that the number of species found is similar to what we have found in the present study. This fact may demonstrate that the pollution effects superimpose themselves onto the natural environmental factors, limiting the establishment of non-opportunistic species and facilitating the development of the opportunistic ones. Those species that are abundant in polluted areas are obviously tolerant to the pollutants to which they are subjected, whereas other species can manifest their sensitivity to the same pollutants by their absence [44].

The accumulation of pollutants in coastal areas does not rely entirely on the supply of these materials by rivers, but also on the chemical interaction between those elements and the sediment constituents, and are therefore reflected by the carbon and fine sediment contents, which more easily adsorb these types of particles [42]. Such environments present high food concentration for several opportunistic species, a fact revealed in the present study by the occurrence of Bolivina spp., Bolivina pulchella, Pseudononion atlanticum, Fursenkoina pontoni, Buliminella elegantissima, Bolivina striatula, Bulimina marginata, Quinqueloculina spp., Ammonia tepida, and Elphidium excavatumand the good positive correlation with organic carbon and PAH of 76\%.

Studies of foraminifera related to the pollution of Guanabara Bay [14] [52] showed this region is seriously impacted. If we compare their conclusions with TSB we will see that, in spite of dominance by opportunistic species, TSB is less impacted in regard to foraminifera. It was observed that stations 20, Cab 1 to Cab 4, Cam 1 and Cam 4 present different fauna from the other stations. At the mentioned stations, natural continental runoff limits species diversity. Compared to the samples collected in the RLAM subtidal area, the samples collected in the Caboto and Camamu control regions presented few individuals, low species numbers and the smallest diversities, suggesting that the control areas are not environments like those in the RLAM area and, therefore, were not wholly comparable. In the MDS analysis, it was possible to see that in July 2004 the rest of the samples formed three groups with more similarity. One of the groups comprised stations 22, 23, 24, 25, with the highest diversities; a second group comprised the least diverse stations 1, 2, 3, 4, 5, and 6; and the last one encompassed stations $9,10,11,12,14,18$, and 19 , with medium diversities. According to the division of the study area based on granulometric characteristics, it was found that the more diverse stations 22, 23, 24, and 25 presented predominance of silt and clay, while the least diverse stations showed predominance of very fine and fine sands, except for station 6, where coarse sand predominated. The last group, containing stations with medium diversities also presented a predominance of silt and clay, except for stations 12 and 14 where coarse sand predominated. The diversity variation at the stations may be linked to the amount of organic matter available and to the capacity to retain this food source used by the foraminifers. Sediments with high predominance of silt and clay contain a great amount of retained organic matter, making the environment suitable for the establishment of different species.

Analysis of relative abundances suggests that the species Gaudryina exillis, Textularia earlandi, Arenoparrella mexicana, Haplophragmoides wilberti, Trochammina sp., Ammotium spp., Ammoastuta inepta, and Miliammina fusca, which occur in places more subjected to continental runoff, were grouped and are characteristic mainly of stations 1, 2, 3, 4, and 5. The marine species Uvigerina sp. is rarely found in the study region, since they are usually associated with colder water masses. Low abundance of the marine species Nonionella opima, 
Fissurina sp., Poreoponides lateralis, Oolina sp. Cibicides spp., Ammodiscus sp., Discorbis spp., and Triloculina sp. was also found. In January 2005 the influence of marine species was found mainly at stations 6, 12, 13, 19, 22, 23 and 25 where we can find Discorbis spp. [12] studying the São Sebastião Channel (São Paulo state, Brazil), [48] studying the Bertioga Channel (São Paulo state, Brazil), and [14] studying Guanabara Bay (Rio de Janeiro state, Brazil) suggest that the occurrence of this species was related to high-density marine currents penetrating via bottom water. Therefore, in the south region of the RLAM subtidal area, the penetration of themarine current was evidenced by the presence of Discorbis in that region.

High-diversity peaks were observed in the central and eastern regions of the RLAM subtidal area, while smaller values were found in the northern region close to the mouth of the Mataripe River and immediately offshore from the RLAM. That region displays a high dominance of Ammonia tepida.

In relation to evenness, there was an increase in the summer from stations 16 to 25 , indicating greater environmental stability at those stations. This stability indicates that the low riverine runoff with consequent stratification break down creates environments that are healthier for foraminifera.

Our results show also that evenness is distributed along a gradient, where lower environmental stability values occur close to the RLAM and the Mataripe River continental runoff, and higher environmental stability occurs toward the ocean (stations 21 to 25) to the south. As environmental stress increases, species diversity falls, resulting in an increase of dominance [53].

The north-to-south diversity increase probably reflects local hydrodynamism, where the saline waters are responsible for water renovation in the southern portion of TSB. The data obtained in the present study reveal that the northern sector, including the regions close to the RLAM, are low-circulation zones, and are thus less subject to water renovation. The analysis carried out over two consecutive years shows a relative environmental stability in terms of foraminifera. The higher diversity found in the second monitoring year reflected the inclusion of stations with more marked euhaline characteristics in the RLAM subtidal area (stations 21 to 25) and therefore do not have an apparent relation to eventual interannual changes.

\section{Conclusions}

The region's fluctuations in salinity and temperature established different tolerance limits for certain species, which indicate that species distribution was subject to natural environmental seasonal changes. In the present study, many marine species were observed, indicating a strong influence due to intrusion of marine waters from the adjacent continental shelf.

Given that opportunistic-tolerant species directly benefit from certain kinds of contamination (organic substances) or indirectly through the reduction of competition and predation, increasing in their occurrence, the present study reveals that the TSB study region is an environment where organic matter is easily deposited, and that the excess of nutrients results in a fauna with little diversity, dominated by Ammonia tepida in the areas closer to riverine runoff. The occurrences of Elphidium excavatum and Quinqueloculina spp. are limited to the eastern part of the area studied in TSB. Pseudononion atlanticum and Buliminella elegantissima occurred in the area under low continental runoff influence.

\section{Acknowledgements}

We thank PETROBRAS for the opportunity to sample and analyze the material discussed in the present text. We also thank FUNDESPA (Fundação de estudos e Pesquisa aquáticas) for their valuable work on the management of the project. The first author is grateful to Dr. Helenice Vital and the funding agency Capes (Coordenação de aperfeiçoamento de Pessoal de nivel superior) through the Edital Ciências do Mar 207/2010 for the Post Doc Fellowship at the Laboratório de Geologia e Geofísica Marinha e Monitoramento Ambiental da Universidade Federal do Rio Grande do Norte (GGEMMA-UFRN-Brazil) providing the means for this research to be published.

\section{References}

[1] Murray, J.W. (1991) Ecology and Palaeoecology of Benthic Foraminifera. Logman Scientific \& Technical, London, $1-397$.

[2] Alve, E. (1991) Benthic Foraminifera in Sediment Cores Reflecting Heavy Metal Pollution in Sorfjord, Western Norway. Journal of Foraminiferal Research, 21, 1-19. http://dx.doi.org/10.2113/gsjfr.21.1.1 
[3] Alve, E. (1995) Benthic Foraminiferal Responses to Estuarine Pollution: A Review. Journal of Paleontology, 25, 190204. http://dx.doi.org/10.2113/gsjfr.25.3.190

[4] Zaninetti, L., Brönnimann, P., Beurlen, G. and Moura, J.A. (1977) La mangrove de Guaratiba et la Baie de Sepetiba, Etat de Rio de Janeiro, Brésil: Foraminifères et écologie. Archives Science Geneve, 30, 161-178.

[5] Brönnimann, P. (1978) Recent Benthonic Foraminifera from Brazil-Morphology and Ecology: Part 3. Notes on Asterothrochammina Bermuda and Seiglie. Notes du laboratoire de Paléontologie, Univ. de Gèneve, 3, 1-8.

[6] Brönnimann, P. (1979) Recent Benthonic Foraminifera from Brazil-Morphology and Ecology: Part 4. Trochaminids from the Campos Shelf with Description of Paratrochammina n. gen. Paleontologische Zeitschrifft, Stuttgart, 63, 5-25.

[7] Brönnimann, P. (1980) Recent Benthonic Foraminifera from Brazil-Morphology and Ecology: Part 5. Primitive Agglutinated Foraminifera from the Campos and Bahia Shelf. Paleontologische Zeitschrift, Stuttgart, 64, 67-89.

[8] Brönnimann, P. and Beurlen, G. (1977) Recent Benthonic Foraminifera from Brazil-Morphology and Ecology. Part 1. Polystommininae, New Subfamily. The Trochaminidae and Description of Polystomamminina planulata (Mikhale Vitali), from the Campos Shelf. Archives des Sciences Gèneve, 30, 77-90.

[9] Brönnimann, P. and Beurlen, G. (1977b) Recent Benthonic Foraminifera from Brazil-Morphology and Ecology. Parts 2 and 3. Cribostomoides Cushman and Haplophragmoides Cushman from the Campos Shelf. 4. Trochammina brasilienses. Brönnimann and Beurlen, n sp. From the Campos Shelf. Archives des Sciences Gèneve, 30, 243-262.

[10] Brönnimann, P. and Dias-Britto, D. (1982) New Lituolacea (Protista, Foraminiferida) from Shallow Waters of the Brazilian Shelf. Journal of Foraminiferal Research, 12, 13-23. http://dx.doi.org/10.2113/gsjfr.12.1.13

[11] Eichler, B.B., Debenay, J.P., Bonetti, C. and Duleba, W. (1995) Répartition des foraminifères benthiques dans la zone sud-ouest du système estuarien-lagunaire d’Iguape-Cananéia (Brésil). Boletim do Instituto Oceanográfico, 43, 1-17. http://dx.doi.org/10.1590/S0373-55241995000100001

[12] Eichler, B.B., Cardoso, P.B.P.K., Souza, S.H.M.E., Furtado, V.V. and Eichler, P.P.B. (2009) Foraminíferos como indicadores biológicos de massas de água. In: Pires-Vanin, A.M.S., Org., Oceanografia de um ecossistema subtropical São Paulo, Editora Universidade de São Paulo, São Paulo, 368-379.

[13] Duleba, W. and Debenay, J.P. (2003) Hydrodynamic Circulation in the Estuaries of Estação Ecológica Juréia-Itatins, Brazil, Inferred from Foraminifera and Thecamoebian Assemblages. Journal of Foraminifera Research, 33, 62-93. http://dx.doi.org/10.2113/0330062

[14] Eichler, P.P.B., Eichler, B.B., Miranda, L.B., Pereira, E.R.M., Kfouri, P.B.P., Pimenta, F.M., Bérgamo, A.L. and Vilela, C.G. (2003) Benthic Foraminiferal Response to Variations in Temperature, Salinity, Dissolved Oxygen and Organic Carbon, in the Guanabara Bay, Rio de Janeiro, Brazil. Anuário do Instituto de Geociências, 26, 36-51. http://ppegeo.igc.usp.br/scielo.php?pid=S0101-97592003000100005\&script=sci_arttext\&tlng=pt

[15] Resig, J.M. (1960) Foraminiferal Ecology around Oceans Outfalls off Southern California. In: Pearson, P.A., Ed., Waste Disposal in the Marine Environment, Pergamon Press, London, 104-121.

[16] Watkins, J.G. (1961) Foraminiferal Ecology around the Orange County, California, Ocean Sewer Outfall. Micropaleontology, 7, 199-206. http://dx.doi.org/10.2307/1484279

[17] Henriquez, J.G., Barichivich, J.C.V. and Mera, J.G.V. (1978) Foraminíferos bentonicos recientes como indicadores de contaminacion litoral en canal Tenglo ( $41^{\circ} 30^{\prime} \mathrm{S} ; 7^{\circ} 59^{\prime} \mathrm{W}$ ) Chile. Seminario para optar al titulo de Ingeniero de Ejecución en Agricultura, Universidad de Chile, Santiago, 1-115.

[18] Setty, A. and Nigam, R. (1982) Foraminiferal Assemblages \& Organic Carbon Relationship in Benthic Marine Ecosystem of Western Indian Continental Shelf. Indian Journal of Marine Science, 11, 225-232.

[19] Sharifi, A.R., Croundance, W. and Austin, R.L. (1991) Benthic Foraminiferids as Pollution Indicators in Southampton Water, Southern England, UK. Journal of Micropaleontology, 10, 109-113.

[20] Yanko, V., Arnold, A. and Parker, W. (2003) Effects of Marine Pollution on Benthic Foraminifera. In: Sen Gupta, B.K., Ed., Modern Foraminifera, Part II, Kluwer Academic Publishers, New York, 217-235.

[21] du Chatelet, E.A., Debenay, J.-P. and Soulard, R. (2004) Foraminiferal Proxies for Pollution Monitoring in Moderately Polluted Harbors. Environmental Pollution, 127, 27-40. http://dx.doi.org/10.1016/S0269-7491(03)00256-2

[22] Bergin, F., Kucuksezgin, F., Uluturhan, E., Barut, I.F., Meric, E., Avsar, N. and Nazik, A. (2006) The Response of Benthic Foraminifera and Ostracoda to Heavy Metal Pollution in Gulf of Izmir (Eastern Aegean Sea). Estuarine, Coastal and Shelf Science, 66, 368-386. http://dx.doi.org/10.1016/j.ecss.2005.09.013

[23] Eichler-Coelho, P., Duleba, W., Eichler, B.B. and Coelho, C. (1996) Influência do rompimento da barragem do Valo Grande (Iguape, SP), nas associações de foraminiferos e tecamebas. Revista Pesquisas, 23, 35-39.

[24] Eichler-Coelho, P., Duleba, W., Eichler B.B. and Coelho, C. (1997) Determinação do impacto ecológico do Valo Grande (Iguape, SP), a partir das associações de foraminiferos e tecamebas. Revista Brasileira de Biologia, 57, 463477. 
[25] Eichler, P.P.B., Eichler, B.B., Pimenta, F.M., Pereira, E. da R.M. and Vital, H. (2014) Evaluation of Environmental and Ecological Effects Due to the Accident in an Oil Pipe from Petrobras in Guanabara Bay, RJ, Brazil. Open Journal of Marine Science, 4, 298-315. http://dx.doi.org/10.4236/ojms.2014.44027

[26] Vilela, C.G., Batista, D.S., Batista-Neto, J.A., Crapez, M. and Mcallister, J.J. (2004) Benthic Foraminifera Distribution in High Polluted Sediments from Niterói Harbor (Guanabara Bay), Rio de Janeiro, Brazil. Anais Academia Brasileira de Ciências, 76, 161-171.

[27] dos Santos, P.T., Vilela, C.G., Neto, J.A.B., Sanjinés, A.E.S., Sanjinés, A.E.S., Aldana, Y.C.P. and Pugirá, M. da S. (2007) Análise multivariada de dados ecológicos da baía de Guanabara-RJ, com base em foraminíferos bentônicos. Anuário do Instuto de Geociências, 30, 101-108.

[28] Eichler, P.P.B., Eichler, B.B., Sen Gupta, B. and Rodrigues, A.R. (2012) Foraminifera as Indicators of Marine Pollutant Contamination on the Inner Continental Shelf of Southern Brazil. Marine Pollution Bulletin, 64, 22-30. http://dx.doi.org/10.1016/j.marpolbul.2011.10.032

[29] PETROBRAS/FUNDESPA (2003) Diagnóstico Ambiental Marinho da Área de Influência da Refinaria Landulpho Alves Mataripe (DAMARLAM). Relatório Final, São Paulo, 1-30.

[30] PETROBRAS/FUSP (2005) Programa de Monitoramento Ambiental do Ecossistema Estuarino na Área de Influência da Refinaria Landulpho Alves (PROMARLAM). Relatório Final, São Paulo, 1-33.

[31] GDB, Governo do Estado da Bahia (2000) Saneamento ambiental da Báia de Todos os Santos. Diagnóstico da qualidade das águas da BTS (Estudos preliminares, fontes de poluição, legislação e metodologia). Report, Salvador.

[32] Venturini, N. and Tommasi, L.R. (2004) Polycyclic Aromatic Hydrocarbons and Changes in the Trophic Structure of Polychaete Assemblages in Sediments of Todos os Santos Bay, Northeastern, Brazil. Marine Pollution Bulletin, 48, 97 107. http://dx.doi.org/10.1016/S0025-326X(03)00331-X

[33] Castro Filho, B.M., Miranda, L.B. and Miyao, S.Y. (1987) Condições hidrográficas na plataforma continental ao largo de Ubatuba: Variações sazonais e em média escala. Boletim do Instituto Oceanográfico, 35, 135-151.

[34] Harvell, C.D., Kim, K., Burkholder, J.M., Colwell, R.R., Epstein, P.R., Grimes, D.J., Hofmann, E.E., et al. (1999) Emerging Marine Diseases_Climate Links and Anthropogenic Factors. Science, 285, 1505-1510. http://dx.doi.org/10.1126/science.285.5433.1505

[35] Muniz, P., Danulat, E., Yannicelli, B., Alonso, J.G., Medina, G. and Bicego, M. (2004) Assessment of Contamination by Heavy Metals and Petroleum Hydrocarbons in Sediments of Montevideo Harbour (Uruguay). Environment International, 29, 1019-1028. http://www.sciencedirect.com/science/article/pii/S0160412003000965

[36] Tavares, T.M., Roch, V.C., Porte, C., Barceló, D. and Albaigés, J. (1988) Application of the Mussel Watch Concept in Studies of Hydrocarbons, PCBs and DDT in the Brazilian Bay of Todos os Santos (Bahia). Marine Pollution Bulletin, 19, 575-578. http://dx.doi.org/10.1016/0025-326X(88)90022-7

[37] Boltovskoy, E. and Wright, R. (1976) Recent Foraminifera. Junk, The Hague, 515 p. http://dx.doi.org/10.1007/978-94-017-2860-7

[38] Newman, M.C. (1995) Quantitative Methods in Aquatic Ecotoxicology. Lewis Publisher, Boca Raton.

[39] Zar, J.H. (1984) Biostatistical Analysis. 2nd Edition, Prentice-Hall, Inc., Englewood Cliffs, 718 p.

[40] Clarke, K.R. and Warwick, R.M. (1994) Changes in Marine Communities: An Approach to Statistical Analyses and Interpretation. Natural Environment Research Council, Plymouth.

[41] Sen Gupta, B.K., Turner, R.E. and Rabalais, N.N. (1996) Seasonal Oxygen Depletion in Continental Shelf Waters of Louisiana: Historical Record of Benthic Foraminifers. Geology, 24, 227-230. http://dx.doi.org/10.1130/0091-7613(1996)024<0227:SODICS>2.3.CO;2

[42] Baptista-Neto, J.A., Silva, M.A. and Figueiredo Jr., A.G. (1996) Padrão de distribuição de sedimentos na Enseada de Jurujuba (Baía de Guanabara, RJ, Brasil). Revista Brasileira de Geofísica, 14, 51-57.

[43] Eichler, P.P.B., Billups, K. and Velez, C.C. (2010) Investigating Faunal and Geochemical Methods for Tracing Salinity in an Atlantic Coastal Lagoon, Delaware, USA. Journal of Foraminiferal Research, 40, 14-33. http://dx.doi.org/10.2113/gsjfr.40.1.16

[44] Yanko, V., Kronfeld, J. and Flexer, A. (1994) Response of Benthic Foraminifera to Various Pollution Sources: Implications for Pollution Monitoring. Journal of Foraminiferal Research, 24, 1-17. http://dx.doi.org/10.2113/gsjfr.24.1.1

[45] Duleba, W., Debenay, J.P. and Sousa, S.H.M. (2004) Caracterização ambiental dos estuários dos Rios Guaraú e Una, a partir de análises sedimentológicas e das associações de foraminíferos e tecamebas. In: Marques, O. and Duleba, W., Eds., Estação Ecológica Juréia-Itatins-Ambiente Físico, Flora e Fauna, Editora Holos, São Paulo.

[46] Sen Gupta, B.K. and Machian-Castillo, M.L. (1992) Benthic Foraminifera on the Northern in Oxygen-Poor Habitats. Marine Micropaleontology, 20, 183-201. http://dx.doi.org/10.1016/0377-8398(93)90032-S

[47] Sen Gupta, B.K. (1999) Systematics of Modern Foraminifera. In: Sen Gupta, B.K., Ed., Modern Foraminifera, Kluwer 
Academic Publishers, Dordrecht, 7-36.

[48] Eichler, P.P.B., Eichler, B.B., Miranda, L.B. and Rodrigues, A.R. (2007) Modern Foraminiferal Facies in a Subtropical Estuarine Channel, Bertioga, Sao Paulo, BRAZIL. Journal of Foraminiferal Research, 37, 234-247. http://dx.doi.org/10.2113/gsjfr.37.3.234

[49] Rabalais, N.N. and Turner, R.E. (2001) Hypoxia in the Northern Gulf of Mexico: Description, Causes and Change. In: Rabalais, N.N. and Turner, R.E., Eds., Coastal Hypoxia: Consequences for Living Resources and Ecosystems, Coastal and Estuarine Studies 58, American Geophysical Union, Washington DC, 1-36. http://dx.doi.org/10.1029/CE058p0001

[50] Phleger, F.B. (1970) Foraminiferal Populations and Marine Marsh Processes. Limnology and Oceanography, 15, 522534. http://dx.doi.org/10.4319/lo.1970.15.4.0522

[51] Debenay, J.P., Eichler, B.B., Guillou, J.-J., Eichler-Coelho, P., Coelho, C. and Porto-Filho, E. (1997) Comportement des peuplements de foraminifères et comparaison avec l'avifaune dans une lagune fortement stratifiée: La Lagoa da Conceição (S.C., Brésil). Revue Paléobiologie, 16, 55-75.

[52] Pereira, E.R., Eichler, P.P.B. and Eichler, B.B. (2004) Foraminifera as Proxies in Environmental Diagnostic in Guanabara Bay, RJ. Journal of Coastal Research, 39, 1395-1398.

[53] Odum, E.P. (1988) Fundamentos da Ecologia. 4th Edition, Fundação Calouste Gulbenkian, Lisboa, 1-927. 